\title{
Journal of Adventure Education and Outdoor Learning
}

\section{VOLUME 13 NUMBER 2 JUNE 2013}

\section{CONTENTS}

\section{Call for papers}

\section{Articles}

Woven into the fabric of experience: residential adventure education and complexity

Randall Williams

The desire to learn as a kind of love: gardening, cooking, and passion in outdoor education

Karen Wistoft

More than relations between self, others and nature: outdoor education and aesthetic experience

fohn Quay

'It's good for their self-esteem': the substance beneath the label Mark Leather 